\title{
pengembangan buku cerita bergambar BERBASIS KARAKTER \\ UNTUK PEMBelaJARAN MEMBACA SISWA SD KELAS IU
}

\author{
RINA PURWANI \\ Fakultas Sosial, Ekonomi, dan Humaniora \\ Universitas Nahdlatul Ulama Purwokerto \\ Email: purwanirina20@gmail.com
}

Pertama Diterima: 26 Oktober 2020

Bukti Akhir Diterima: 30 Desember 2020

\begin{abstract}
Abstrak
Penelitian pengembangan dengan desai Research and Development (R\&D) ini dilatarbelakangi oleh minat baca anak yang masih kurang dan tidak didukung adanya bahan bacaan atau cerita anak yang bermutu. Buku cerita yang berkembang di pasaran sebagian besar ialah buku cerita anak yang berbasis bergambar dan bersifat khayli sehingga tidak dapat merangsang pola pikir anak. Meski tetap mengandung nilai moral dan nilai pendidikan yang dapat dicontoh, tetapi cerita tersebut hanya dapat dijadikan sarana hiburan. Buku cerita bergambar merupakan media yang unik dan menarik dengan menggabungkan gambar dan teks dalam bentuk yang kreatif. Tujuan penelitian ini adalah mendeskripsikan kebutuhan pengembangan buku cerita bergambar, mendeskripsikan karakteristik kebutuhan pengembangan buku, memperoleh hasil pengujian produk buku sehingga layak digunakan sebagai pembelajaran membaca siswa SD. Penelitian ini merupakan penelitian pengembangan dengan tujuh tahap penelitian yaitu mulai dari analisis kebutuhan sampai dengan uji terbatas produk. Penelitian dilakukan di tiga sekolah sampel di kota Purwokerto, yaitu SD N 2 Karanglewas Lor, SD N 1 Bantarsoka, SD N 1 Pasir Kidul. Instrumen data yang digunakan meliputi : pedoman pengamatan, pedoman wawancara, angket dan instrumen penilaian pakar. Hasil penelitian ini menunjukkan bahwa produk telah baik dan layak sebagai sarana sumber belajar. Selanjutnya berdasarkan hasil uji keefektifan produk dalam pembelajaran penggunaan gambar yang menarik,kalimat yang jelas, komunikatif juga memudahkan peserta didik dalam memahami materi/isi buku tersebut.
\end{abstract}

Kata kunci: cerita bergambar, berbasis karakter, pembelajaran membaca

\begin{abstract}
This development research with the design of Research and Development ( $R \& D)$ is motivated by the lack of children's reading interest and is not supported by any quality children's reading material or stories. Most of the story books that are developing in the market are children's story books which are based on pictures and are fictional in nature so that they cannot stimulate children's thinking patterns. Even though it still contains moral values and educational values that can be emulated, the story can only be used as a means of entertainment. The picture story book is a unique and interesting medium by combining images and text in a creative form. The purpose of this study was to describe the need for picture book development, describe the characteristics of the needs for book development, to obtain the results of book product testing so that it is suitable for use as learning to read elementary students. This research is a development research with seven stages of research, starting from needs analysis to limited product testing. The research was conducted in three sample schools in the city of Purwokerto, namely SD N 2 Karanglewas Lor, SD $N 1$ Bantarsoka, SD N 1 Pasir Kidul. The data instruments used include: observation guidelines, interview guidelines, questionnaires and expert assessment instruments. The results of this study indicate that the product is good and feasible as a learning resource. Furthermore, based on the results of the product effectiveness test in learning the use of attractive images, clear, communicative sentences, it also makes it easier for students to understand the material / content of the book.
\end{abstract}

Key words: picture story, character based, reading learning 


\section{PENDAHULUAN}

Perkembangan ilmu pengetahuan dan teknologi telah membawa perubahan cepat di segala bidang, terutama di bidang pendidikan. Salah satu penunjang pendidikan dasar supaya berjalan secara optimal adalah dengan menanamkan kebiasaan membaca sejak dini. Kebiasaan membaca merupakan salah satu kunci keberhasilan seseorang dalam meraih ilmu pengetahuan dan teknologi. Buku bacaan adalah salah satu media yang sangat efektif untuk mengembangkan kreativitas dan imajinasi anak. Buku yang tepat untuk hal ini adalah buku-buku fiksi atau bergambar meskipun tidak tertutup kemungkinan juga berupa buku-buku non fiksi (Thomas dalam Yulia 2005: 10).

Salah satu hal yang dapat meningkatkan kecerdasan anak adalah dengan aktivitas membaca. Membaca merupakan salah satu keterampilan berbahasa yang harus dimiliki oleh seorang siswa. Dari kegiatan membaca siswa mendapat banyak informasi, informasi yang berkembang belakangan ini ialah mendidik anak agar gemar membaca sedari dini. Hal ini perlu dikembangkan karena aktivitas membaca dapat merangsang anak untuk berpikir kritis dan logis. Melalui bacaan tersebut anak dapat belajar pengalaman orang lain dalam menghadapi masalah kehidupan.

Kesadaran akan pentingnya membaca seperti itu tidak didukung adanya bahan bacaan atau cerita anak yang bermutu. Buku cerita yang berkembang di pasaran sebagian besar ialah buku cerita anak yang berbasis bergambar dan bersifat khayali. Padahal corak cerita yang demikian tidak dapat merangsang pola pikir anak. Meski tetap mengandung nilai moral dan nilai pendidikan yang dapat dicontoh, namun cerita tersebut hanya dapat dijadikan sarana hiburan saja.

Fakta lain yang sering dijumpai yaitu pada minat baca anak yang masih kurang. Meski bahan bacaan sudah tersedia namun anak masih enggan untuk membacanya. Hal ini juga sangat disesali, sebab buku-buku yang ada tidak dapat mendatangkan daya tarik dan daya rangsang anak untuk membacanya. Fenomena semacam ini kerap terjadi pada sekolah dasar yang berada di pinggiran. Sekolah dasar yang menggunakan fasilitas serba seadanya.

Kenyataan yang terjadi sebagian besar siswa SD tidak mengenal buku cerita terlebih buku cerita bergambar. Mereka lebih memilih televisi dan game untuk mengisi waktu mereka di luar sekolah. Hal ini menjadikan siswa tidak peka terhadap hal-hal yang terjadi di sekitar mereka. Apalagi tentang karakter siswa yang kerapkali membuat kegaduhan, membangkang, melawan terhadap guru. Hal tersebut merupaka salah satu dampak gagalnya penerapan karakter yang di tanamkan sejak usia dini. Siswa cenderung tak acuh terhadap permasalahan sosial yang terjadi di sekitar.

Minat siswa dalam membaca perlu diperbaiki. Pemerintah juga ikut ambil bagian dalam hal tersebut. Salah satunya dengan upaya untuk melakukan Gerakan Literasi Sekolah (GLS) yang diwujudkan melalui kegiatan wajib membaca 15 menit sebelum pelajaran dimulai. Selain itu, penggunaan buku cerita bergambar juga dapat menimbulkan rasa ketertarikan tersendiri bagi siswa untuk membacanya. Buku cerita bergambar merupakan media yang unik dengan menggabungkan gambar dan teks dalam bentuk yang kreatif. Buku cerita bergambar dirancang untuk menarik perhatian agar siswa mau membacanya. 
Permasalahan yang ada tersebut perlu diatasi agar minat baca siswa meningkat. Dalam hal ini peran seorang guru sangat menetukan terhadap peningkatan minat baca siswa. Seorang guru harus dapat lebih memahami apa yang dibutuhkan siswa mulai dari bagaimana proses belajar itu terjadi serta langkah-langkah apa yang diperlukan, sehingga dapat dilakukan dengan baik sesuai dengan tujuan pembelajran. Selama pembelajaran berlangsung dibutuhkan komunikasi berupa interaksi antara guru dan siswa, agar dapat berjalan dengan baik dibutuhkan alat bantu yang disebut media pembelajaran. Media pembelajaran adalah segala sesuatu yang dapat digunakan untuk menyalurkan pesan dari pengirim ke penerima sehingga dapat merangsang pikiran, perasaan, perhatian, dan minat siswa sehingga proses belajar terjadi (Sadiman, et all 2008:7). Salah satu yang dapat digunakan sebagai media pembelajaran siswa SD adalah buku cerita bergambar yang mengandung banyak ilustrasi.

Buku cerita bergambar juga dapat menimbulkan respon positif pada diri anak yang membacanya. Setiap respon positif yang dimunculkan anak akan memperlancar hubungan antarneuron. Secara tidak langsung, cerita merangsang otak untuk menganyam jaringan intelektual anak (Musafiroh 2008:21). Buku cerita bergambar yang dimaksud bukanlah sejenis komik. Buku cerita bergambar merupakan bentuk cerita yang dihiasi dengan ilustrasi isi cerita berupa gambar. Melalui buku cerita bergambar pun, kemampuan anak untuk mengingat kembali informasi yang pernah diterimanya mulai terasah. Kemampuan mengingat kembali ini akan sangat berguna pada perkembangannya sebagai makhluk individu dan sosial yang bermoral dan berakhlak baik.

Buku cerita bergambar untuk siswa sekolah dasar perlu untuk dikembangkan. sebagian siswa lebih tertarik dengan buku yang lebih banyak gambar dan warna. Selain tiu, mereka lebih senang membaca buku cerita bergambar dari pada pelajaran karena kalimatnya mudah dipahami. Melihat karakteristik anak yang pada dasarnya senang dengan cerita yang dilengkapi dengan gambar dan berwarna-warni, cerita bergambar sebagai salah satu jenis cerita anak dapat menjadi alternatif penanaman nilai-nilai pendidikan karakter tersebut. Anak dapat menikmati teks cerita sekaligus berimajinasi dengan mudah melalui gambar yang diilustrasikan, sehingga anak dengan senang hati mencontoh perilaku yang tercerminkan dalam tokoh pada cerita yang dibaca.Cerita anak menjadi salah satu jalan mewujudkan kaidah dasar bahwa penanaman nilai karakter dapat dilakukan tanpa kesan memaksa dan menekan. Bahkan, nilai-nilai yang terdapat dalam cerita anak dapat membentuk benih-benih sikap positif. Sikap positif yang dibentuk secara terus-menerus dapat menjadi karakter anak setelah mereka dewasa.Cerita itu sendiri adalah penuturan tentang suatu kejadian. Di dalam cerita tersebut dapat diketahui di mana, bagaimana, dan apa yang dialami oleh pelaku cerita dari awal sampai akhir. Pelaku cerita dapat manusia, binatang, dan benda-benda lain (Arifin 2009: 38). Ia menambahkan di dalam cerita membahas suatu topik tertentu yang dideskripsikan secara kronologis. Di samping itu, topik tersebut harus mampu menumbuhkan daya nalar anak.

Cerita bergambar yang merupakan produk dari sastra anak sengaja diciptakan untuk anakanak. Selain sebagai sarana hiburan, cerita bergambar juga dapat digunakan dalam pembelajaran. Hal tersebut sesuai dengan pernyataan Sudjana dan Rivai (2002:27) bahwa cerita bergambar sebagai media grafis yang dipergunakan dalam proses pembelajaran memiliki pengertian praktis, yaitu dapat mengkomunikasikan fakta-fakta dan gagasan-gagasan secara jelas dan kuat melalui perpaduan antara pengungkapan kata-kata dan gambar. Melalui daya nalar mereka dapat 
berimajinasi melihat buku cerita bergambar yang menyertakan teks atau gagasan-gagasan yang memiliki pesan moral dan gambar yan menarik.

Daya nalar dan rasa ingin tahu anak dalam mengikuti jalan cerita semakin terpancing dengan adanya dukungan gambar sebagai ilustrasi dalam cerita. Ilustrasi merupakan gambar atau bentuk visual lain yang menyertai teks. Dengan adanya gambar atau ilustrasi yang mendampingi teks, akan mempermudah anak untuk mengembangkan imajinasinya. Mempermudah anak memproyeksikan dirinya ke dalam cerita tersebut. Sehingga ilustrasi gambar dalam sebuah cerita tidak dapat dibuat secara asal.

Ilustrasi gambar adalah gambaran singkat alur cerita suatu cerita guna lebih menjelaskan salah satu adegan (Rahim 2007:46). Secara umum ilustrasi selalu dikaitkan dengan menjelaskan sebuah cerita agar lebih jelas. Selain itu, ilustrasi memiliki fungsi (1) memberikan bayangan setiap karakter di dalam cerita; (2) memberikan bayangan bentuk alat-alat yang digunakan di dalam tulisan ilmiah; (3) memberikan bayangan langkah kerja; (4) mengkomunikasikan cerita; (5) menghubungkan tulisan dengan kreativitas dan individualitas manusia; dan (6) memberikan humorhumor tertentu untuk mengurangi rasa bosan (Rohmah: 2006: 34).

Dalam Kamus Besar Bahasa Indonesia (1993: 232), karakter adalah sifat-sifat kejiwaan, akhlak atau budi pekerti yang membedakan seseorang dengan yang lain.(Samani dan Hariyanto 2011: 48) karakter dimkanai sebagai cara berpikir dan berperilaku yang khas tiap individu untuk hidup dan bekerjasama baik dalam lingkungan keluarga, masyarakat, bangsa dan negara. Pendidikan karakter dimaknai sebagai pendidikan yang mengembangkan nilai-nilai karakter pada diri peserta didik sehingga mereka memiliki nilai dan karakter sebagai karakter dirinya, menerapkan nilai-nilai tersebut dalam kehidupan dirinya, sebagai anggota masyarakat dan warga negara yang religius, nasionalis, produktif, dan kreatif (Pusat Perbukuaan 2007).

Dalam Kamus Besar Bahasa Indonesia (2009:215) istilah budi pekerti diartikan sebagai tingkah laku, perangai, akhlak dan watak. Budi pekerti dalam bahasa Arab disebut dengan akhlak, dalam kosa kata latin dikenal dengan istilah etika dan dalam bahasa Inggris disebtu ethics. Senada dengan itu Balitbang Puskur (2010:12) menjelaskan bahwa budi pekerti secara konsepsional adalah budi yang dipekertikan (dioperasionalkan, diaktualisasikan atau dilaksanakan) dalam kehidupan sehari-hari dalam kehidupan pribadi, sekolah, masyarakat, bangsa dan negara. Budi pekerti secara operasional merupakan suatu prilaku positif yang dilakukan melalui kebiasaan. Artinya seseorang diajarkan sesuatu yang baik mulai dari masa kecil sampai dewasa melalui latihan-latihan, misalnya cara berpakaian, cara berbicara, cara menyapa dan menghormati orang lain, cara bersikap menghadapi tamu, cara makan dan minum, cara masuk dan keluar rumah dan sebagainya.

Tujuan yang hendak dicapai dalam penanaman karakter sebagai berikut.

a) Mengembangkan potensi kalbu/nurani/afektif peserta didik sebagai manusia dan warganegara yang memiliki nilai-nilai dan karakter yang baik.

b) Mengembangkan kebiasaan dan perilaku peserta didik yang terpuji dan sejalan dengan nilainilai universal dan tradisi budaya bangsa yang religius.

c) Menanamkan jiwa kepemimpinan dan tanggung jawab peserta didik sebagai generasi penerus bangsa. 
d) Mengembangkan kemampuan peserta didik menjadi manusia yang mandiri, kreatif, berwawasan kebangsaan.

e) Mengembangkan karakter kehidupan sekolah sebagai karakter belajar yang aman, jujur, penuh kreativitas dan persahabatan, serta dengan rasa kebangsaan yang tinggi dan penuh kekuatan.

Berdasarkan uraian tersebut jelas bahwa cerita bergambar adalah produk dari sastra anak yang menyampaikan pesan lewat dua cara, yaitu lewat gambar (ilustrasi) dan tulisan. Gambar dan tulisan tidak berdiri sendiri, tetapi saling mendukung untuk menyampaikan pesan sehingga kedudukan antara gambar dan tulisan saling menguatkan. Cerita dalam cerita bergambar juga seringkali berkenaan dengan pribadi atau pengalaman pribadi sehingga pembaca (anak-anak) mudah mengidentifikasi dirinya melalui perasaan serta tindakan dirinya melalui perwatakan tokohtokoh utamanya.

Dengan membaca cerita anak siswa SD terutama akan tumbuh menjadi seorang pribadi yang memiliki pengetahuan luas dan kecerdasan emosi yang baik. Oleh sebab itu, dengan adanya buku cerita bergambar yang mengedepankan konsep penanaman karakter pada anak sejak usia dini diharapakan dapat meningkatkan keterampilan dan minat baca serta mencetak generasi penerus yang berkarakter, bermoral, dan berakhlak baik.

Sekolah Dasar (SD) sebagai jenjang pendidikan terendah dalam hierarki sistem pendidikan di Indonesia berfungsi untuk menanamkan kemampuan dan keterampilan agar dapat melanjutkan ke jenjang pendidikan yang lebih tinggi. Selain itu, Sekolah Dasar (SD) juga berfungsi untuk memberi bekal yang cukup kepada siswa dalam mengembangkan diri sesuai dengan potensi diri. Oleh karena itu, penanaman pengetahuan mengenai bagaimana menanamkan atau menumbuhkan nilai-nilai karakter sangat penting dilakukan sedari dini sebagai bekal mereka pada masa mendatang.

\section{METODE PENELITIAN}

Desain penelitian ini menggunakan pendekatan Research and Development (R\&D) dengan tujuh tahap penelitian (Sugiyono, 2010). Penelitian diawali dari survei pendahuluan yaitu menemukenali potensi masalah yang ada di lapangan (Tahap 1) selanjutnya dilakukan awal analisis kebutuhan setelah mendapatkan data kemudian disusun prototipe pengembangan produk (tahap 2), pengembangan prototipe buku cerita bergambar untuk pembelajaran membaca siswa SD, sebelum diujicobakan prototipe yang sudah disusun diujikan terlebih dahulu kepada dosen ahli (tahap 3). Tahap selanjutnya yaitu validasi produk, tujuannya untuk memberikan penilaian dan saran masukan terhadap prototipe yang disusun (tahap 4), revisi desain produk tujuannya untuk merevisi produk yang sudah mendapat revisi dari validator (tahap 5), tahap berikutnya adalah uji coba terbatas berupa revisi prototipe dan perbaikan (tahap 6), dantahap terakhir yaitu deskripsi hasil penelitian berupa tahap akhir pengembangan produk (tahap 7).

Dalam penelitian ini peneliti menentukan tiga sekolah sebagai sampel penelitian yaitu, SD N 2 Karanglewas Lor, SD N Pasir Kidul, dan SD N 1 Bantarsoka. Untuk menjaring data kebutuhan buku digunakan 30 siswa dan 4 guru kelas IV dari masing-masing sekolah dasar. Instrumen yang digunakan untuk menjaring data awal penelitian dengan menggunakan wawancara, observasi, angket kebutuhan, dan lembar uji validasi. Angket digunakan untuk memperoleh data tentang 
kebutuhan buku cerita bergambar pada peserta didik. Teknik wawancara dan angket kebutuhan ditujukan kepada guru dan peserta didik untuk menjaring data yang dibutuhkan dalam penyusunan buku pengayaan. Setelah data terkumpul kemudian data dianalisis dengan teknik dengan teknik analisis deskriptif kualitatif dan analisis kuantitatif. Analisis deskriptif kualitatif digunakan untuk mengungkapkan dan memperoleh data kebutuhan pengembangan materi cerita bergambar. Adapun analisis kuantitatif digunakan untuk mengetahui keberterimaan hasil pengembangan materi buku cerita bergambar berbasis karakterbagi siswa.

\section{HASIL DAN PEMBAHASAN}

\section{1) Analisis Kebutuhan Peserta Didik Terhadap Buku Cerita Bergambar Berbasis Karakter untuk Pembelajaran Membaca Siswa SD}

Berdasarkan hasil analisis kebutuhan peserta didik dibagi menjadi tiga aspek, (A) aspek tanggapan siswa terhadap isi cerita berbasis karakter. Aspek tanggapan siswa terhadap isi cerita berbasis karakter diperoleh berdasarkan angket kebutuhan yang diberikan kepada siswa. Aspek tanggapan siswa terhadap isi cerita meliputi empat indikator seperti (1) siswa lebih memilih buku cerita yang dilengkapi dengan gambar sebagai bahan bacaan, (2) unsur intrinsik cerita yang terintegrasi dengan konsep konservasi karakter, (3) siswa memilih dimensi isi materi cerita sesuai harapan siswa, dan (4) siswa tertarik pada buku yang disajikan dengan menarik. (B) Aspek karakteristik buku cerita berbasis karakter (bentuk fisik buku) siswa membutuhkan buku cerita dengan panduan yang sederhana sekaligus menarik. Tidak terlepas dari indikator penyajian isi, indikator bahasa dan grafika juga demikian. Siswa mengharapkan bahasa yang sederhana dan mudah dimengerti, komunikatif serta tidak bertele-tele. Sama halnya dengan indikator grafika, ilustrasi gambar pada nomor halaman dan di dalam cerita harus disesuaikan dengan isi cerita yaitu berbasis karakter, dan (C) aspek harapan terhadap buku cerita, siswa membutuhkan buku cerita bergambar berbasis karakter sebagai bahan bacaan yang mengandung unsur pengetahuan sarana belajar bagi siswa.

\section{2) Analisis Kebutuhan Guru Terhadap Buku Cerita Bergambar Berbasis Karakter untuk Pembelajaran Membaca Siswa SD}

Analisis kebutuhan guru pun akan terbagi atas tiga aspek (A) aspek tanggapan guru terhadap isi cerita berbasis karakter. Aspek tanggapan guru terhadap isi cerita berbasis karakter terdiri atas (1) guru lebih memilih buku cerita yang dilengkapi gambar sebagai bahan pembelajaran, (2) unsur intrinsik cerita yang terintegrasi konsep karakter, (3) guru memilih dimensi isi materi sesuai harapan masing-masing. (B) karakteristik buku cerita bergambar berbasis karakter, hampir seluruh guru membutuhkan panduan memahami cerita yang sederhana dan menarik serta materi yang singkat dan komunikatif agar siswa mudah memahami isi buku tersebut. Selain tiu, Guru membutuhkan judul, cover, desain buku, pewarnaan, nomor halaman, jumlah cerita, dan ilustrasi gambar yang menarik dan sesuai kebutuhan. dan (C) harapan terhadap buku cerita. Berdasarkan hasil angket kebutuhan guru terhadap buku cerita bergambar berbasis karakter diketahui bahwa buku cerita dapat dijadikan sebagai bahan pembelajaran, selain itu buku cerita tersebut dapat menambah ilmu pengetahuan siswa terutama mengenai karakter. Dari kegiatan membaca buku cerita bertema karakter, siswa 
dapat memahami nilai-nilai kejujuran, kedisiplinan, ketekunan, dan peduli terhadap sesama untuk kemudian diaplikasikan ke dalam kegiatan sehari-hari.

\section{3) Prinsip-prinsip Pengembangan Buku Cerita Bergambar Berbasis Konservasi Karakter}

Berdasarkan hasil analisis angket kebutuhan siswa dan guru tersebut maka dapat dicapai prinsip-prinsip pengembangan buku cerita bergambar berbasis karakter. Ada beberapa dimensi yang dapat dijadikan sebagai prinsip-prinsip pengembangan buku cerita bergambar berbasis karakter untuk pembelajaran membaca siswa SD Berikut adalah pemaparan prinsipprinsip pengembangan buku cerita bergambar berbasis karakter tersebut.

\section{a. Dimensi Sampul Buku}

Prinsip-prinsip yang menjadi dasar penyusunan sampul buku, yaitu (1) keserasian warna. Warna sampul buku yang diharapkan mayoritas responden siswa dan guru adalah dominan berwarna hijau. Warna hijau dipilih karena lebih pantas untuk menggambarkan suasana alam. Berdasarkan data tersebut, maka warna cover buku pun disesuaikan dengan kebutuhan siswa dan guru. Dengan demikian, warna yang dijadikan sampulbuku adalah dominan berwarna hijau. (2) penataan gambar. Gambar yang dijadikan sebagai cover buku adalah gambar-gambar kartun. Hal ini sesuai dengan keinginan mayoritas responden siswa dan guru, yaitu lebih memilih gambar kartun. Gambar kartun yang akan dijadikan cover disesuaikan dengan tema buku cerita tersebut, yaitu cerita-cerita yang mengandung nilainilai pendidikan karakter. Sesuai keinginan siswa, gambar yang berada dalam sampul yaitu gambar tokoh dan keadaan karakter.Penataannya pun dibuat sedemikian rupa agar tampak menarik dan menimbulkan kesan cinta karakter dalam diri siswa. (3) penataan tulisan. Penataan tulisan pada sampul buku disusun sedemikian rupa sehingga para pembaca tertarik untuk membacanya. Jenis huruf dan ukuran huruf pun disesuaikan agar terkesan indah dan menarik pembaca. Penataan tulisan ini bertuliskan judul buku dan nama penulis pada bagian depan sampul. Begitu juga di bagian punggung buku bertuliskan judul buku dan nama penulis, sedangkan pada bagian belakang cover dicantumkan gambaran umum kumpulan cerita yang dirangkum di dalam buku cerita bergambar, dan (4) jenis sampul. Berdasarkan keinginan siswa dan guru, sampul tebal/ hard cover menjadi pilihan mayoritas dengan alasan supaya tidak mudah robek mengingat siswa . merupakan siswa yang aktif. Untuk itu, jenis sampul yang akan dijadikan sampul pada buku cerita ini ialah jenis sampul tebal. Hal tersebut mengingat jenis sampul tebal menjadi pilihan mayoritas responden.Berikut pemaparan dari keempat aspek tersebut.

\section{b. Dimensi Anatomi Buku}

Pada dimensi anatomi buku, yang dijadikan sebagai prinsip yaitu (1) jumlah halaman, Sebagian besar responden siswa mengharapkan buku cerita anak dengan jumlah halaman sekitar 30 halaman. Berbeda dengan siswa, responden guru mengharapkan sekitar 20-50 halaman. (2) kelengkapan isi (pendahuluan, nas atau isi, penyudah), Pada bagian isi, peneliti menyajikan cerita-cerita anak yang memaparkan karakter anak seperti nilai-nilai kejujuran, ketekunan, peduli terhadap sesama. Pemilihan jenis cerita tersebut disesuaikan dengan keinginan sebagian besar responden yang lebih menyukai cerita nyata/realistik. Pada bagian akhir cerita terdapat hikmah cerita yang bisa kita ambil dari masing-masing isi cerita. 
(3) tata letak/sistematika gambar dan teks, Berkaitan dengan tata letak atau sistematika buku, peneliti dibantu tim ilustator untuk mendesain layout yang semenarik mungkin, mengingat sasaran buku cerita ini adalah siswa SD. Hal ini dilakukan agar mereka tidak bosan membaca buku cerita anak tersebut. Dengan demikian, nilai-nilai karakter yang terkandung dalan cerita dapat tersampaikan dengan baik(4) jenis huruf, sebagian besar jenis huruf yang digunakan adalah myriad pro dan best marker agar terkesan lebih unik dan menarik. Selain itu, pemilihan jenis huruf tersebut juga sesuai dengan hasil pilihan responden siswa. (5) ukuran buku, Buku cerita bergambar yang akan disusun peneliti adalah buku cerita dengan ukuran sedang yaitu $20 \times 20 \mathrm{~cm}$. Hal tersebut sesuai keinginan responden siswa dan guru yang menginginkan buku ukuran sedang dengan alasan agar praktis tidak terlalu besar dan tidak terlalu kecil dan (6) nomor halaman. Berdasarkan jawaban responden, nomor halaman akan diletakkan pada tengah ujung kanan.

\section{c. Dimensi Isi Buku}

Dimensi isi buku yang dijadikan sebagai prinsip, yaitu (1) konsep buku, sesuai dengan pilihan sebagian besar responden, konsep buku ini adalah buku kumpulan cerita anak dengan ilustrasi dengan ukuran 20 × $20 \mathrm{~cm}$ yang ada materinya. Dari itu, penulis pun tidak hanya menyajikan kumpulan cerita anak saja, melainkan juga turut menyajikan materi mengenai konsep karakter.

(2) Jenis cerita,adapun cerita nyata tersebut dapat cerita keluarga, dan cerita sekolah. Lebih spesifik lagi, responden siswa dan guru memilih cerita sekolah dan keluarga. Berdasarkan data tersebut, kedua jenis cerita tersebut akan penulis masukan ke dalam buku cerita mengingat faktor variasi cerita agar anak tidak lekas bosan jika hanya menceritakan cerita sekolah saja.

(3) Kebutuhan materi,materi yang disampaikan dalam buku ini adalah sekilas pandang mengenai masalah tentang kerusakan karakter. Selain itu, peneliti juga memberikan materi mengenai cara membaca yang menyenangkan.Mengingat produk yang dibuat peneliti adalah buku kumpulan cerita anak, materi yang disampaikan pun hanya berupa materimateri secara garis besar.

(4) Penggunaan kata dan kalimat,penggunaan kata maupun kalimat dalam buku cerita anak berbasis karakter ini disesuaikan dengan kondisi siswa sebagai pelajar maupun guru. Kata dan kalimat yang digunakan tetap mengedepankan pada kejelasan dan kemudahan pembaca untuk memahami isi cerita sehingga semua nilai yang ada dalam tiap cerita akan tersampaikan. Kosa kata yang dipilih juga sederhana, sesuai dengan tingkat perkembangan anak agar siswa lebih memahami jalan cerita.

(5) Cerita mengenai karakter,buku cerita anak yang akan penulis susun adalah buku cerita anak berbasis karakter untuk meningkatkan kepedulian terhadap karakter. Oleh karena itu, cerita-cerita yang ada dalam buku tersebut merupakan cerita-cerita yang mengandung nilai karakter untuk meningkatkan kepedulian terhadap sesama, menanamakan kejujuran, ketekunan dan saling tolong menolong antar sesama. 
(6) Judul,sesuai dengan keinginan siswa dan guru, judul yang tepat untuk buku cerita berbasis karakter ini adalah Arsakha si Jagoan Kecil Judul tersebut dianggap paling tepat untuk mewakili cerita yang bertema karakter.

(7) Karakteristik ilustrasi gambar, penyusunan ilustrasi gambar telah disesuaikan dengan keinginan mayoritas responden, yaitu menggunakan gambar kartun berwarna. Untuk pemilihan warna pada buku tersebut akan menggunakan warna-warna lembut. Sesuai dengan keinginan, gambar akan dibuat dengan ukuran sedang dan berada pada halaman terpisah dengan teks. Hal ini dikarenakan supaya siswa bebas menikmati gambar dan tulisan.

\section{4) Validasi Buku Cerita Bergambar Berbasis Karakter untuk Pembelajaran Membaca Siswa SD}

Sebelum digunakan dalam proses pembelajaran, buku cerita bergambar berbasis karakter divalidasi oleh dua orang validator yaitu dosen ahli dan pendidik atau praktisi. Validasi dilakukan untuk mengukur kelayakan buku cerita bergambar sesuai dengan kriteria penilaian buku, yaitu kelayakan 1) isi/materi, 2) penyajian, 3) kebahasaan, dan 4) kegrafikkan. Hasil validasi menunjukkan bahwa dari seluruh aspek buku cerita bergambar yang berbasis karakter yang divalidasi berkategori baik dari segi bentuk fisik penyajian maupun isi/materi dalam buku.

Penyusunan buku cerita anak berbasis karakter disusun sesuai dengan acuan dan pertimbangan hasil analisis kebutuhan siswa dan guru. Sampul buku cerita anak berbasis karakter dikomposisikan antara warna, gambar, dan tulisan yang dikemas secaara menarik. Adapun produk pengembangan dalam penelitian ini sebelum dan setelah divalidasi dapat dilihat pada gambar berikut ini.

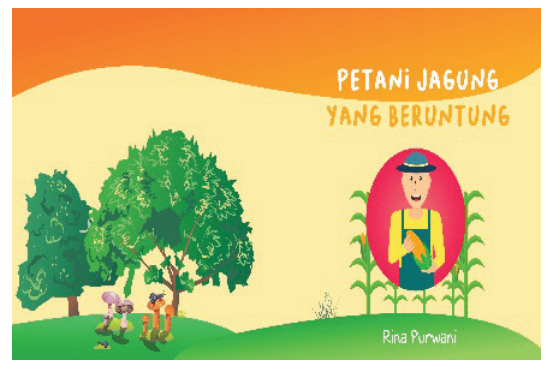

Gambar 1 Gambar Sampul Sebelum Perbaikan

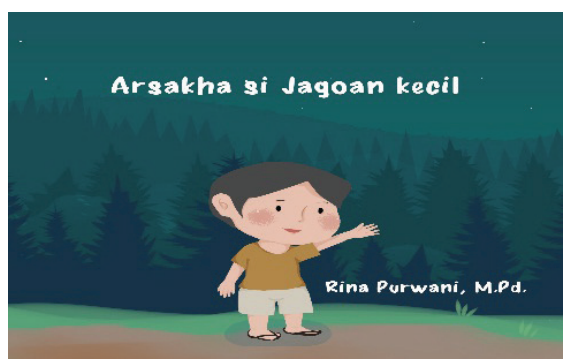

Gambar 2 Gambar Sampul Setelah Perbaikan

\section{a. Halaman Pendahulu}

Perbaikan yang dilakukan pada halaman pendahuluan buku cerita bergambar berbasis karakter meliputi beberapa hal, yaitu (1) penggantian Judul Buku dari Petani Jagung yang Beruntung menjadi Arsakha si Jagoan Kecil, pergantian judul tersebut dilakukan karena isi cerita judul Petani Jagung yang Beruntung belum mewakili karakter 
anak yang mencakup kejujuran, hidup berkecukupan, ketekunan (2) penggantian layout daftar isi (3) penggantian kalimat pada halaman sekilas tentang karakter pada halaman 1 dan 2. Penggantian kalimat tersebut dilakukan karena sebelumnya bahasa yang digunakan masih terlalu tinggi dan perlu disederhanakan. Untuk lebih jelasnya, dapat dilihat pada Tabel 1 di bawah ini

\section{Tabel 1 Perbaikan pada Halaman Pendahuluan}

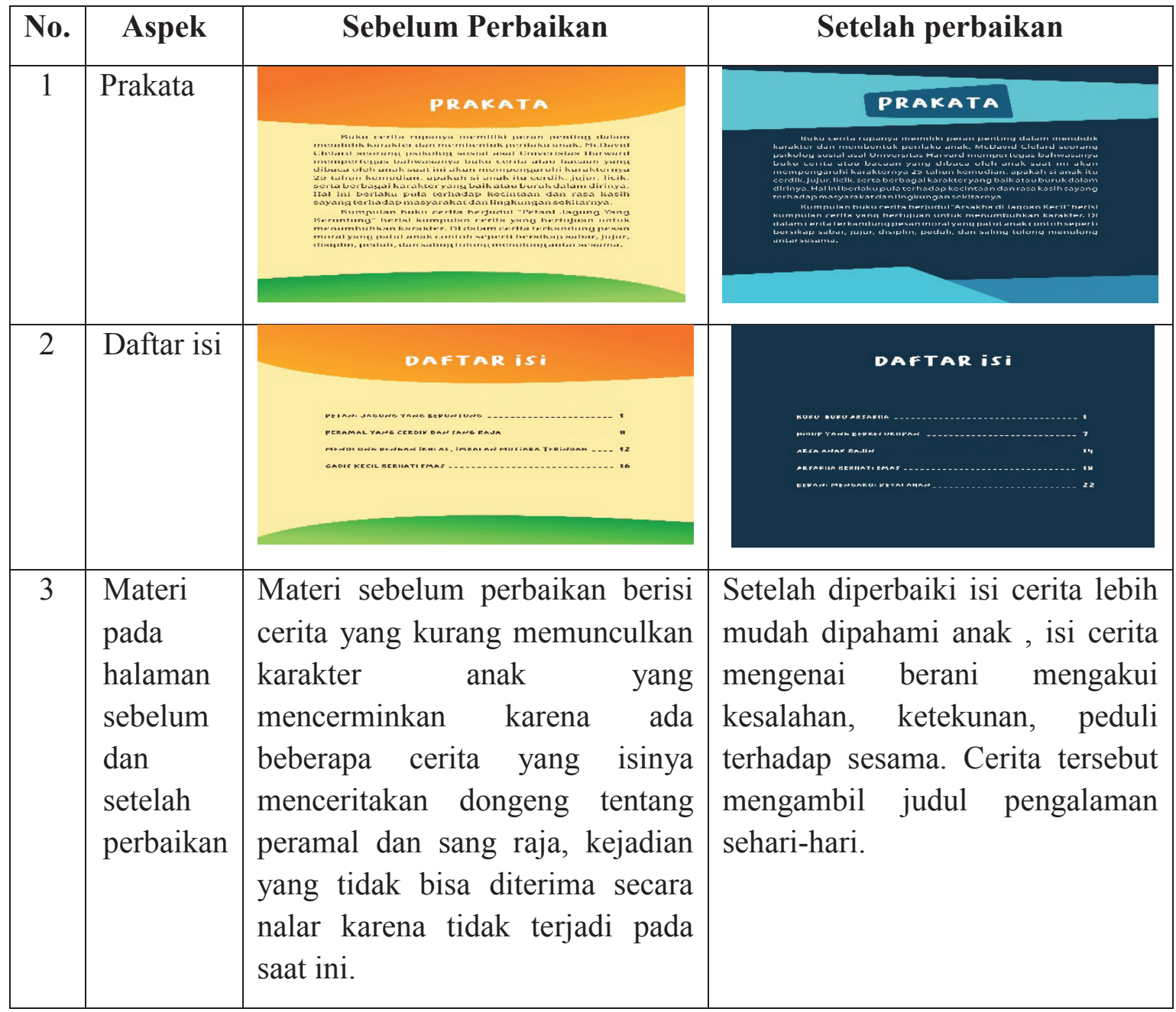

\section{b. Halaman Teks Isi}

Pada halaman teks isi penulis banyak melakukan perbaikan terhadap cerita. Hal ini dikarenakan cerita yang ada sudah belum mengandung unsur-unsur karakter. Perbaikan pertama, penulis melakukan perbaikan pada tulisan-tulisan dalam kotak sebagai cuplikan atau pesan yang dapat diambil. Sebelumnya kalimat dalam kotak tersebut masih berupa informasi saja belum mengandung ajakan. Sehingga penulis menggantinya dengan menggunakan kalimat himbauan. Kedua, perbaikan dilakukan pada setiap paragraf yang belum menjorok ke tengah. Untuk lebih jelasnya terdapat dalam gambar 4.6 dan 4.7 berikut ini. 


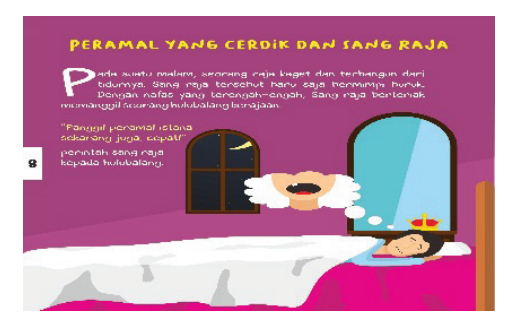

Gambar 3 Sebelum Perbaikan

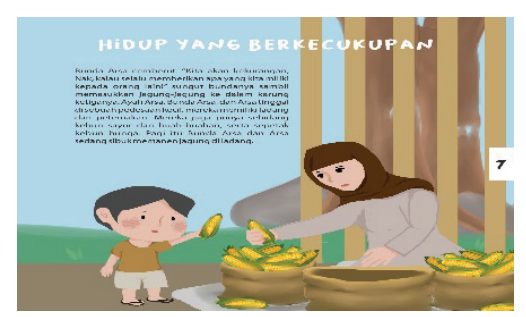

Gambar 4 Setelah Perbaikan

\section{c. Halaman Penyudah}

Perbaikan yang dilakukan pada halaman penyudah adalah lay out diseting ulang agar lebih menarik, halaman biografi penulis sebelum revisi belum terdapat foto penulis ditambahkan foto penulis setelah direvisi. Pada bagian isi terletak pada pemilihan bahasa yang dianggap kurang dapat diterima oleh siswa SD.

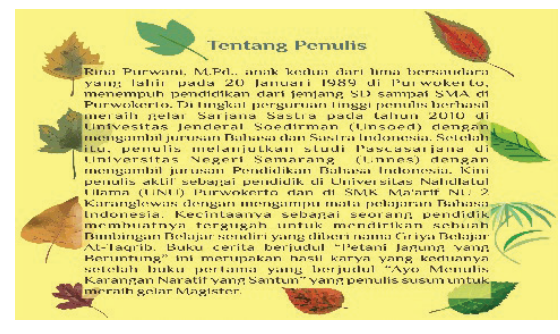

Gambar 5 Sebelum Perbaikan

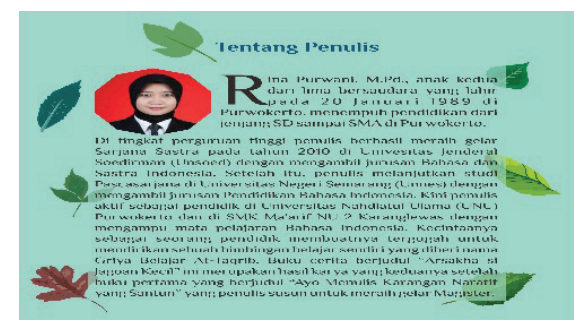

Gambar 6 Setelah Perbaikan

\section{Pembahasan}

Penelitian ini telah diusahakan agar sesuai dengan prosedur penelitian dan pengembangan yang peneliti lakukan. Kekurangan dan keterbatasan dalam penelitian perlu diungkapkan agar tidak terjadi salah persepsi. Keterbatasan yang dimaksud menyangkut beberapa aspek, yaitu: (1) sumber data, (2) instrumen penelitian, (3) pengujian prototipe buku cerita, dan (4) bahan penyerta penyusunan buku cerita. Uraian dari keempat aspek tersebut adalah sebagai berikut.

Sumber data yang digunakan untuk mengambil data dalam penelitian ini adalah siswa dan guru SD dari 3 sekolah berbeda di kota Purwokerto yaitu SDN 2 Karanglewas Lor, SDN Bantarsoka, dan SD N Pasir Kidul. Siswa yang diambil dari tiap sekolah adalah sebagian siswa kelas IV. Guru yang dijadikan sebagai sumber data dalam hal ini adalah dua guru kelas IV dari masing-masing sekolah tempat penelitian. Jadi, data yang diperoleh dari tiap sekolah berbeda karena bergantung pada jumlah siswa kelas IV.

Instrumen yang digunakan dalam penelitian ini bukanlah instrumen yang sepenuhnya baku sesuai dengan aturan yang ada, sehingga memungkinkan data yang diperoleh sebagaimana mestinya dan sesuai dengan harapan. Instrumen yang dibutuhkan untuk pengembangan buku cerita bergambar berbasis karakter untuk pembelajaran membaca siswa SD adalah angket dan lembar uji validasi prototipe. 
Pengujian dan penilaian prototipe buku cerita bergambar berbasis karakter dilakukan pada 20 siswa kelas IV dari masing-masing sekolah yang menjadi sumber data penelitian. Pengujian belum sepenuhnya dilakukan melalui pengawasan peneliti secara langsung. Kondisi demikian menyebabkan penilaian belum sepenuhnya ideal sesuai kebutuhan dan harapan.

Hal-hal yang berkenaan dengan buku cerita bergambar berbasis karakter adalah pemilihan materi, gambar, dan cerita yang disajikan. Materi yang disertakan sebatas mengenai pemahaman awal mengenai kerusakan-kerusakan karakter yang terjadi di Indonesia. Materi karakter terintegrasi dalam cerita. Setiap cerita menanamkan karakter anak agar terbentuk menjadi lebih baik di masa sekarang dan akan datang, hal itu meliputi nilai-nilai kejujuran, ketekunan, dan peduli terhadap sesama. Ilustrasi gambar dikerjakan oleh illustrator, layout buku secara keseluruhan baik warna maupun tulisan, sepenuhnya dilakukan oleh ahli yang berasal dari Jurusan Bahasa dan Sastra Indonesia, UNSOED.

\section{SIMPULAN DAN SARAN}

\section{Simpulan}

Pertama, berdasarkan analisis terhadap buku cerita bergambar berbasis karakter, siswa maupun guru membutuhkan buku cerita bergambar tersebut. Selain dapat digunakan dalam proses pembelajaran, siswa dapat mengenal dan mengetahui nilai-nilai karakter seperti kejujuran, kedisiplinan, ketekunan, berbagi dan saling tolong menolong yang nantinya dapat menumbuhkan kepedulian siswa terhadap sesama manusia.

Kedua, buku cerita bergambar yang diharapkan adalah buku cerita dengan ukuran sedang agar praktis. Di samping itu, buku cerita bergambar tersebut disusun dengan ketebalan yang disesuaikan dengan kondisi dan keinginan anak. Sesuai keinginan responden, buku tersebut mengandung delapan cerita bertema karakter.

Ketiga, penilaian dan saran perbaikan prototipe buku cerita bergambar berbasis karakter untuk pembelajaran membaca siswa SD. Berdasarkan penilaian yang diberikan oleh guru dan ahli, yaitu (1) dimensi sampul buku, perolehan nilai rata-rata 77,9 dengan kategori baik, (2) dimensi halaman pendahulu buku, perolehan nilai rata-rata 80,2 dengan kategori baik, (3) dimensi halaman teks isi, perolehan nilai rata-rata 88,4 dengan kategori sangat baik.

Keempat, tanggapan siswa terhadap buku cerita bergambar berbasis karakter untuk pembelajaran membaca siswa SD. Data didapat melalui angket tanggapan. Siswa memberikan pernyataan setuju terhadap beberapa pernyataan yang diajukan, seperti (1) siswa setuju bahwa materi yang disampaikan mudah dipahami, (2) siswa setuju bahwa gambar yang disajikan sesuai dengan isi cerita dan saling melengkapi, (3) siswa setuju bahwa pemaparan alur cerita mudah diikuti dan dicerna, (4) siswa setuju penggunaan bahasa dan kalimat mudah dipahami, (5) siswa setuju judul pada buku tersebut sesuai dengan isi cerita dan menarik untuk dibaca, (6) siswa sangat setuju bahwa tampilan cover bagus dan menarik, (7) siswa setuju dengan jenis dan ukuran huruf karena dapat terbaca dengan jelas, (8) siswa setuju dengan ketebalan buku karena memang disusun sesuai kebutuhan mereka, (9) siswa setuju pada ukuran buku yang disusun sesuai dengan harapan 
mereka, (10) siswa setuju bahwa buku tersebut dapat menarik minat baca untuk menumbuhkan karakter anak.

\section{Saran}

Pertama, untuk menumbuhkan minat baca sekaligus rasa peduli terhapap karakter pada diri siswa, hendaknya siswa diperkenalkan dengan buku yang mengandung nilai-nilai karakter. Salah satu cara untuk menjembatani hal tersebut ialah melalui buku cerita. Melalui cerita, siswa dapat mengenal dan menerapkan nilai-nilai karakter dalam kehidupannya sehari-hari tanpa unsur paksaan.

Kedua, para pemerhati pendidikan hendaknya dapat mengadakan pengembangan terhadap buku cerita anak bergambar yang berbasis karakter untuk melengkapi berbagai buku cerita yang sudah ada di pasaran. Dengan adanya buku cerita bergambar berbasis karakter yang mengedepankan konsep menjaga, memperbaiki, dan melestarikan karakter, siswa tidak hanya memperoleh hiburan, melainkan mendapatkan pengetahuan lebih dalam mengenai karakter.

Ketiga, perlu diadakan penelitian lebih lanjut untuk menguji efektivitas buku cerita bergambar berbasis karakter pada pembelajaran di sekolah dasar. Pengujian lebih lanjut ini akan menghasilkan saran dan perbaikan yang dapat dimanfaatkan untuk memperbaiki kualitas produk agar lebih sempurna. 


\section{DAFTAR PUSTAKA}

Arifin, Zainal. 2009. Evaluasi Pembelajaran. Bandung: PT Remaja Rosdakarya

Balitbang Puskur. 2010. Pengembangan Pendidikan Budaya dan Karakter Bangsa. Pedoman Sekolah. Jakarta : Kemdiknas Balitbang Puskur.

Depaertemen Pendidikan Indonesia. 1993. Kamus Besar Bahasa Indonesia Pusat Bahasa. Jakarta : PT. Gramedia Pustaka

Depaertemen Pendidikan Indonesia. 2009. Kamus Besar Bahasa Indonesia Pusat Bahasa. Jakarta : PT. Gramedia Pustaka.

Faizah, Umi. 2009. Keefektifan Cerita Bergambar untuk Pendidikan Nilai dan Keterampilan Berbahasa dalam Pembelajaran Bahasa Indonesia. Artikel dalam Jurnal Cakrawala Pendidikan: Th. XXVIII No. 3, November 2009.

Majid, Abdul Aziz Abdul. 2002. Mendidik dengan Cerita. Bandung: PT Remaja Rosdakarya Offset.

Muchlas Samani dan Hariyanto. 2011. Pendidikan Karakter. Bandung : Remaja Rosdakarya.

Musafiroh, Tadkiroatun. 2008. Perkembangan Kecerdasan Majemuk. Jakarta: Grasindo.

Nurgiyantoro, Burhan. 2002. Teori Pengkajian Fiksi. Yogyakarta: Gajah Mada University Press.

Pusat Perbukuan. 2007. Pedoman Peniliaan Buku Pengayaan Kepribadian. Jakarta : Depdiknas.

Rahim, Farida. 2007. Pengajaran Membaca di Sekolah Dasar. Jakarta: Bumi Aksara.

Rohmah, Galuh Nur. 2006. Nilai Cerita Anak dan Kesusastraan dalam Menciptakan Pendidikan Humanis bagi Anak Indonesia. Artikel dalam Jurnal Lingua: volume 1, nomor 1 juni 2006.

Rivai. 2002. Pengembangan Buku Ajar. Jakarta : Rineka Cipta

Sadiman, Arief S. dkk. 2008. Media Pendidikan, Pengertian, Pengembangan, dan Pemanfaatannya. Jakarta: PT Raja Grafindo Persada.

Sugiyono. 2010. Metode Penelitian Pendidikan Pendekatan Kuantitatif, Kualitatif, dan R\&D. Bandung: Alfabeta. 
Sumarmi. 2008. Sekolah Hijau sebagai Alternatif Pendidikan Karakter Hidup dengan Menggunakan Pendekatan Kontekstual. Jurnal Ilmu Pendidikan: jilid 15, nomor 1, Februari 2008.

Yulia, Anna dan Thomas. 2005. Cara Menumbuhkan Minat Baca Anak. Jakarta: Gramedia Pustaka Jaya. 